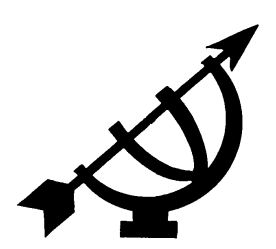

\title{
Analysing Southern African food security: assessing the New Variant Famine hypothesis $^{1}$
}

Gideon van Riet

African Centre for Disaster Studies

Potchefstroom Campus

North-West University

POTCHEFSTROOM

E-mail: Gideon.vanriet@nwu.ac.za

Abstract

Analysing Southern African food security: assessing the New Variant Famine hypothesis

This article investigates the New Variant Famine (NVF) hypothesis coined by Alex De Waal during the 2001-2003 Southern African food security crisis, as a tool for analysing food insecurity in the region. The NVF hypothesis depicts a protracted and extensive famine from which there is very little chance of recovery, in which HIV and AIDS are central to the widespread suffering of people. The author suggests that the role of HIV and AIDS on food security be considered as one contributing factor to a dynamic process(es) of vulnerability and not viewed in isolation. In addition it is suggested that analyses focus on underlying processes driving vulnerability and not on specific instances of "famine" or crisis.

\section{Opsomming}

'n Analise van Suidelik-Afrikaanse voedselsekuriteit met spesifieke verwysing na die Nuwe Variant Hongersnoodhipotese

Hierdie artikel ondersoek die Nuwe Variant Hongersnoodhipotese (NVH), geformuleer deur Alex de Waal gedurende die

1 The author gratefully acknowledges comments made by Dewald van Niekerk and Eric Nealer on earlier drafts of this article as well as comments by three anonymous reviewers. 
2001-2003 voedselsekuriteitkrisis in Suidelike Afrika, as 'n moontlike wyse om voedselsekuriteit in dié streek te bestudeer. Die hipotese stel 'n hongersnood voor wat baie min moontlikheid op herstel bied en waarin MIV en VIGS 'n sentrale rol speel. Die skrywer stel voor dat die rol van MIV en VIGS met betrekking tot voedselsekuriteit as bydraend tot 'n dinamiese proses(se) van kwesbaarheid beskou word en dat dit nie in isolasie beskou word nie. Die skrywer stel verder voor dat analises op onderliggende drywers van kwesbaarheid fokus en nie op spesifieke gevalle van "hongersnood"/krisis nie.

\section{Introduction}

Between 2001 and 2003 Southern Africa suffered a severe food security crisis. This was not the first crisis of such a nature in the region. However, this particular food security crisis was accompanied by substantial HIV and AIDS prevalence rates. De Waal (2003) and De Waal and Whiteside (2003) argued that the food crisis indicated the possibility of a new type of famine, a potentially chronic New Variant Famine (NVF) occurring in the region. The implications of this warning for the region seemed clear enough: HIV and AIDS had to inform interventions aimed at addressing food insecurity. The NVF hypothesis and the manner in which it was adopted by aid organisations have been criticised extensively for a host of reasons. In essence, however, the argument was that the impact of HIV and AIDS on food insecurity, though significant, is overstated.

Both food security and HIV and AIDS are considered two of the most pressing issues in sub-Saharan African development (Kirsten, 2001; Lemke et al., 2001). In addition many have reported on their (often bi-directional) interaction (Barnett \& Whiteside, 2002; Van Lierre, 2002; Save the children, 2004). Thus, a thorough understanding of the relationship between these two factors and the best manner in which to approach analyses of this matter seem necessary.

This article provides an overview of the NVF discourse since 2001 and investigates the prospects for a continuation of the discourse. Firstly certain key concepts are discussed in order to ensure a common understanding of their usage by the author. Secondly an explanation of the logic of the NVF hypothesis is provided. Thereafter key points of criticism are critically evaluated. The article concludes by evaluating the NVF hypothesis as a tool for the analysis of Southern African food security. 


\section{Delineating a few key concepts}

\subsection{Food security}

A definition of the concept food security can be viewed as consisting of three tiers. Firstly there has to be sufficient food available in a country to meet aggregate level needs. However, availability does not ensure food security (Mkandawire \& Matlosa, 1993:8). For individuals and households to have food security, they should also have the ability or means to access or command available food supplies. Therefore, food security relates to both availability and access. A third tier relates to the type of food and accompanying levels of sanitation. Food should be nutritious and safe (also referred to as nutrition security), while not compromising cultural or religious norms. Thus, the following definition can be used:

Food security exists when all people, at all times, have physical and economic access to sufficient, safe and nutritious food for a healthy and active life (Sphere Project, 2004:108).

\subsection{Vulnerability}

As with most concepts in the field of disaster studies/risk reduction, the concept vulnerability has been defined in various ways. According to Van Niekerk (2006:2), the most commonly used definition for vulnerability stems from the UN/ISDR (2004) report Living with risk which defines vulnerability as:

The conditions determined by physical, social, economic and environmental factors or processes, which increase the susceptibility of a community to the impact of hazards.

These "hazards" might originate from the natural environment, such as droughts, floods or sinkholes or may be anthropogenic in nature, for example nuclear meltdowns, pollution or terrorism.

The above definition is quite static. Vulnerability can also be viewed as a process. Wisner et al. (2004:49-86) for example, devised a disaster model, the so-called pressure model. In this model, vulnerability (as an outcome) or "unsafe conditions" are portrayed as the outcome of a progression of various factors contributing to the susceptibility of individuals, households, et cetera to be negatively affected upon the occurrence of a hazard. This article takes the position that vulnerability can be viewed both as an outcome and a process. 


\section{The New Variant Famine hypothesis}

The NVF hypothesis has as its central focus the dynamic interaction between HIV, AIDS and malnutrition specifically in Southern Africa. This dynamic manifests as follows: HIV and AIDS infection imply that those infected require better nutrition and thus cannot afford to skimp on food consumption. Those infected with HIV need sufficient nutrition to combat both HIV as well as opportunistic infections. An HIV positive person needs about $10 \%$ more energy than someone who has not contracted the virus. An AIDS patient needs a minimum of $20 \%$ more energy and up to $50 \%$ more protein, while a good mix of vitamins remains essential (C-SAFE, 2003:19). Thus, a shock to the food supply or a decline in access could be catastrophic to households with HIV positive members. This implies that traditional famine coping mechanisms, such as rationing food and simply eating less are rendered not only ineffective but in fact detrimental to individual health statuses. Malnourished individuals for various reasons are more susceptible to infection (Loevinsohn \& Gillespie, 2003:7). In addition, nutritional status also plays a role in mother to child transmission, the vulnerability to infection for adults, as well as the transition from HIV to AIDS. According to studies cited by Loevinsohn and Gillepsie (2003:7) mothers with strong immune systems are less likely to transmit HIV to their unborn babies. In addition these same authors note that women's better nutrition before and during pregnancy increases birth weight and infant immune status, reducing several "child side" risk factors to infection.

Furthermore, the illness and death of adults (as opposed to children and elderly people in other famines) leads to a decline in food production and a loss of income in general, as well as a change in the make-up of the crops being produced by a household. Sick adults often plant less labour intensive, but also less nutritious crops. The example used by De Waal and Whiteside (2003:4) in this regard is that of cereals being replaced with a crop such as cassava (a tuberous root, high in energy, but low in protein and other nutrients). Others argue similarly, for example, according to UNAIDS (2004:45), HIV and AIDS increase food shortages, in that it reduces the agricultural workforces of many countries. Thus, the loss of income and labour caused by the illness of an adult has to be made up in some other way. Traditional coping mechanisms in this regard include taking children out of school to help grow food crops or to find employment elsewhere. This, however, impacts on the future well-being of that child and his/her family, as he/she is deprived of an education. Families often sell-off household assets to increase 
the short-term supply of money. Thus, the sustainability of food security is jeopardised, as future productivity might be inhibited.

The rural burden emphasised by the NVF hypothesis is further compounded by the need to take care of orphans and sick adults, who move from urban areas to stay with relatives in rural areas. Due to AIDS related deaths of adults, many children are orphaned. This can place extreme financial pressure on extended families. The medical costs involved in treating an ill household member can comprise up to one-third of a household's income (UNAIDS, 2004:45). To this can be added funeral costs, which can be even higher.

The premature death of adults leads to a loss in the transfer of traditional knowledge from parents to children, who in many cases now head households. For example, children may not acquire knowledge about wild fruits and the recipes for preparing them from their dying parents. Children are also not as skilful as their more experienced parents in planning food consumption in times of shortage (De Waal \& Whiteside, 2003:5). This further undermines their nutritional status and makes them more vulnerable to future famines. As with many of the processes described by the NVF hypothesis and HIV and AIDS literature in general, not much is known regarding the extent of this so-called "trans-generational" loss of knowledge.

According to De Waal and Whiteside (2003:8) prospects for household recovery seem to be much less. Both factors are a function of the undermining of coping mechanisms, such as the use of accumulated skills and kinship networks. This leads to an increasing number of young women engaging in transactional sex, which in turn potentially increases HIV transmission. Thus it is argued, HIV and AIDS are potentially causing a protracted and extensive crisis, with no clear solution.

In summary it can thus be stated that a NVF implies a situation where household destitution is brought on by a combination of declined agricultural production, the overextension of financial and social resources (extended family networks) and regressive coping mechanisms (such as transactional sex and the rationing of food), and the premature deaths of adults. The NVF hypothesis has been debated by various academics, practitioners and journalists. The following section discusses these criticisms along with De Waal's rebuttal on key issues. 


\section{Criticism on the NVF hypothesis}

\subsection{The 2001-2003 crisis versus future crises}

There has been a lot of confusion regarding whether De Waal did imply that the 2001-2003 crisis in Southern Africa was in fact a NVF or whether the NVF hypothesis is merely a theory regarding potential future crises. Harvey (2004a:20) notes that many have presented the hypothesis as an explanation of the recent food crisis. This might, however, have resulted from a possible ambiguity in some of De Waal's writings. De Waal and Whiteside (2003:1) for example, state the following in their abstract:

... however, this crisis is distinct from conventional droughtinduced food shortages with respect to those vulnerable to starvation, and the course of impoverishment and recovery. We propose that these new aspects to the food crisis can be attributed largely to the HIVIAIDS epidemic in the region. We present evidence that we are facing a new variant famine.

This extract and other similar phrases may be interpreted as the authors believing that the then present crisis was in fact a NVF. The word "largely" suggests that they believe HIV and AIDS are the most important factors driving food insecurity. Thus, it is not surprising that the bulk of the criticism of the NVF hypothesis is based on the argument that the recent crisis was driven by more than just HIV and AIDS.

\subsection{Use of the concept famine}

On a very basic, yet fundamental level, the NVF hypothesis is criticised by Itano (2003) for the use of the term famine, which she holds is generally defined as mortality rates doubling, coupled with a $20 \%$ increase in acute malnutrition under children (presumably under five). Attendees at a workshop where De Waal presented his thesis in 2003 had similar reservations. These commentators consider a famine to be associated with much more suffering than was in fact observed. De Waal (Tembo, 2003) in response cites Sen, in arguing that a famine does not necessarily imply mass starvation, but rather that it is a process characterised by a lack of access to food.

It seems the more important issue here is the long running debate regarding what constitutes a famine, specifically the tension between what Howe and Devereux (2004) refer to as definitions of famine as an event and definitions of famine as a process. Definitions 
such as the one cited by Itano focuses on certain distinct outcomes, while De Waal and others see it as a regression in food security. The implication of viewing famine as a process for the purposes of this discussion is that it is potentially very difficult to agree or disagree with De Waal, without being vulnerable to arguments based on alternative definitions. It also makes the NVF hypothesis more difficult to cognitively process, possibly fuelling a lot of confusion and criticism and arguably does the NVF hypothesis a lot of harm. It opens up the hypothesis to criticism based on commonsensical definitions. Howe and Devereux (2004:366) state:

A famine is an accelerated process of rising individual malnutrition, household destitution and social breakdown. For a famine to occur there has to be a rapid deterioration in foodsecurity indicators ...

Devereux (2006a; 2000b) also distinguishes between chronic food insecurity and transitory food insecurity. The former entails persistent suffering and the latter typically, coinciding with a shock to production. This distinction refers to the temporal dimension of food insecurity, while in both instances distinctions can be made between various levels of severity. However, chronically food-insecure individuals and households (those "living on the edge"), are often more vulnerable in times of increased stress. From the above it seems that a NVF can be viewed as a process of accelerated destitution where HIV and AIDS are a critical factor in the creating chronic food insecurity, while facilitating many instances of transitory food insecurity turning into chronic suffering. While this logic is disputed, existing levels of chronic vulnerability to hunger/food insecurity in Southern Africa (Drimie \& Misselhorn, 2005:2; Devereux, 2006b:3) should be acknowledged.

\subsection{Food security is driven by more than just HIV and AIDS}

As stated above a common criticism of the NVF hypothesis has been that the 2001-2003 food crisis in Southern Africa was driven by more than just the HIV and AIDS pandemic (e.g. see Ellis, 2003; Wiggins, 2005). Many authors (e.g. Frankenberger et al., 2003; Devereux, 2002; Wiggins, 2005) note the fact that food insecurity in the period from 2001-2003 was the result of both "underlying factors" and "triggers". In other words there was/is an underlying vulnerability to shocks such as droughts and floods (and for that matter HIV infection). Moreover, it is widely argued that numerous factors acted (and arguably still act) in a dynamic manner, overlapping and reinforcing each other, causing and exacerbating food 
insecurity (Drimie, 2005; Wiggins, 2005; United Nations, 2003). These include inter alia HIV and AIDS, failing state capacity and food policy failure, lack of market access, extreme climatic events all of which contribute to or exploit existing levels of poverty.

The discussions presented by De Waal and De Waal and Whiteside have not made significant mention of social, political and economic factors contributing to food insecurity in Southern Africa. Nevertheless De Waal (2001:1) qualifies the NVF hypothesis, by stating that he does not deny the fact that there are other factors contributing to vulnerability. It is, however, the manner in which HIV and AIDS add onto these factors which lead to significant increases in vulnerability. Furthermore, De Waal and Tumushabe (2003:4) in a report to the United Kingdom Department for International Development (DFID) hold that HIV and AIDS increase inequality. For example, there might be those who benefit from the impoverishment of others, as they could obtain access to land, through dispossessing dissolving households, or by hiring cheap labour. Thus, many of the wider impacts of the HIV and AIDS epidemic may not be evident in aggregate level statistics. De Waal (2001) argues similarly in referring to the possibility of AIDS related national crises (ARNC) emerging, wherein HIV and AIDS indirectly impact on various facets of society, such as the Gross National Product (GNP), infected individuals reverting to erratic and illegal behaviour (e.g. corruption) and the death of important skilled workers, such as teachers and medical staff with extensive knock-on effects. All these factors could contribute to vulnerability to HIV and AIDS infection and traditional triggers to food insecurity, such as droughts and floods. Thus, the indirect effects of HIV and AIDS are likely to be very significant, although it might not be easy to observe. However, if the impact of HIV and AIDS at the aggregate level is hard to observe, then the extent of its impact seems hard to prove.

\subsection{The NVF hypothesis's "rural bias"}

The NVF hypothesis has also been criticised for its rural focus. Ellis (2003:17) notes that many deep rural areas might be unaffected and many urban areas might be affected. Thus, the rural vulnerability that AIDS creates might be exaggerated. However, De Waal and Tumushabe (2003:2) cite the International Fund for Agricultural Development (IFAD, 2001) in stating that there is evidence indicating that the agricultural sector is disproportionately affected by HIV and AIDS. This is because the structure of especially the smallholder sector makes it much harder to absorb losses of labour. 
In addition they also state the fact that the overwhelming majority of populations depend on agriculture for their livelihoods. However, evidence from the researchers of the Department of Agricultural Economics at Michigan State University (Mather et al., 2004), pertaining to selected countries in Southern and Eastern Africa, suggests that a loss of labour typically depends on the type of adult death. Thus, the death of a household head/spouse specifically leads to a loss in labour and not the death of adult children which in fact seems to be more common. The fact that labour may be lost due to care being taken of sick adults is, however, still worth considering.

\subsection{The prospects for adapting to HIV-infection}

Ellis (2003:18) notes that the NVF hypothesis is too static. The hypothesis precludes the possibility of adaptation to HIV and AIDS in the region. Thus, according to the NVF hypothesis, the region seems to be doomed and there is nothing that can be done about it. However, there does seem to be some evidence of such adaptation already, as Mather et al. (2004:25) observe labour sharing practices in affected communities in Southern and Eastern Africa between neighbouring households. In addition Mather et al. (2004) found that certain households adapt to adult deaths by taking in new adults.

De Waal (2001:2) notes that macro-economic indicators remain robust, despite the fact of significant suffering at the micro level. This discrepancy is attributed to coping mechanisms. De Waal states that these practices merely postpone the "day of reckoning". Other issues are also important in this regard, such as the consistent erosion of livelihoods in Southern Africa for the last two to three decades, increasing vulnerability (e.g. see Frankenberger et al., 2003 and McEwan, 2003). However, will this "day of reckoning" ever occur or will sustainable coping mechanisms such as labour pooling prevail? This question is central to section five below.

\subsection{The reliability of evidence}

Griekspoor et al. (2004:397) put into question the scientific rigour behind the data used to substantiate the NVF hypothesis. They state that no studies have been published on the impact of HIV and AIDS on urban and peri-urban food security and in "unstable societies", meaning those stricken by, for example, conflict and natural disasters. Furthermore, no studies have observed the link between HIV and AIDS status and the nutritional status of individuals. Rather, socio-economic surveys at the household level have been con- 
ducted, using proxy indicators for HIV prevalence. These include dependency ratios and the number of fostered orphans. Yet, the accuracy of these proxy indicators is largely unknown. Conclusions at the community level are then made based on the data acquired at household levels, even though sampling techniques may not have been all that systematic, thus implying unrepresentative samples. Harvey (2004a:20) states that surveys which have been conducted were small, geographically scattered and not specifically designed for the purpose. This suggests that for theses such as the NVF hypothesis to be validated or refuted, scientists will have to pay significant attention to measuring tools employed when studying the relationship between HIV, AIDS and food security.

\subsection{Informing humanitarian interventions}

There is little doubt that the NVF did inform the humanitarian response to the 2001-2003 food security crisis in Southern Africa to a significant extent, with NGOs incorporating HIV and AIDS proxy indicators (such as chronic illness and orphanhood) into their targeting criteria for food aid. De Waal and Tumushabe (2003:1) note that such targeting criteria have been adopted, among others, by UNICEF and the World Food Programme (WFP). It has, however, been argued that the reason for incorporating HIV and AIDS into responses was a shrewd move to obtain more funding (Scott cited in Bolton, 2003). This might have been a useful strategy in the light of possible donor fatigue with regards to food insecurity. The phrase "new variant fundraising" has been used in this regard (Harvey, 2004b:19). However, the incorporation of HIV and AIDS proxy indicators as a means of targeting for food security was arguably a mistake, specifically with regards to how it was done. Taking HIV and AIDS as an indicator of food insecurity without correlating it to household asset ownership/command, led to targeting errors (TANGO International, 2005). In short: targeting HIV and AIDS affected households, without taking cognisance of their means of coping with the infection, implies providing aid to individuals and households who might not need it.

As the above indicates, the NVF hypothesis is based on evidence that is still being contested. The general agreement seems to be that the NVF hypothesis is not an accurate reflection of the recent/ current situation in Southern Africa. Though many of the processes it describes seem to be substantiated by other literature, the extent of the occurrence of these processes and the number of households affected in this regard can be questioned. In addition, the uncertainty 
surrounding the definition of the term famine complicates the discussion.

Thus, Southern Africa might not yet have experienced a New Variant Famine. However, one might speculate whether the occurrence of food security crises with HIV and AIDS as a central driving force, is a possibility in the future. A confluence of factors could potentially bring this about. Various authors (Frankenberger et al., 2003; McEwan, 2003) have commented on a process of "livelihoods erosion" that has been taking place in various parts of the region over the last few decades. Along with the possible increase or sustained high levels of HIV and AIDS prevalence in the region, this could have dire consequences.

\section{Day of reckoning?}

HIV and AIDS prevalence rate in sub-Saharan Africa have been increasing for decades and are likely to at least be sustained at very high levels for the foreseeable future. Whiteside (2002:313) projects that the current epidemic in Africa will only peak by the year 2022. According to him the generalised epidemic in the region (one primarily driven by heterosexual intercourse, in which at least one percent of women test positive at antenatal clinics), is still to reach its peak. However, UNAIDS (2006) indicates that the epidemics in most of Southern Africa seem to have stabilised at very high levels, though it is still increasing in certain areas, such as Botswana, Mozambique, Northern Malawi and urban areas in Zambia. 2 If capabilities to deal with HIV infection continue to decline, the consequences may be severe.

\subsection{Regressive development/livelihoods erosion}

Various commentators have stated that development in Southern Africa has not only stagnated, but has in fact regressed, and that livelihoods have diminished during the last three decades (e.g. Frankenberger et al., 2003; McEwan, 2003; Drimie, 2005). It seems failures of development have left an increasing amount of households with diminishing livelihoods, severely limiting resilience in

2 UNAIDS (2006) indicates that with the exception of Angola and island states off the coast of the African mainland, latest HIV prevalence estimates in Southern Africa (also including, Botswana, Lesotho, Malawi, Mozambique, Namibia, South Africa, Zambia and Zimbabwe) range between $14,1 \%$ in Malawi and $33,4 \%$ in Swaziland. 
times of crisis and leaving states unable to provide sufficient safety nets to its citizens. This section describes some of the more commonly cited factors that have contributed to diminished livelihoods over the past few decades. This discussion is by no means aimed at being exhaustive. The purpose is solely to illuminate the concept livelihoods erosion. These factors are necessarily to a large extent country specific.

For the purposes of this article, a livelihood is defined as the capabilities, assets (stores, resources, claims and access) and activities required for a means of living, and as sustainable when it can cope with and recover from stress and shocks, maintain and enhance its "capabilities and assets, and provide sustainable livelihood opportunities for the next generation" (Chambers \& Conway, cited by Marsland, 2003:59).

\subsubsection{Macro level impacts}

The 1973 oil crisis triggered a "foreign exchange crisis" in Africa, which fuelled the African "debt crisis". Private loans to the continent dried up and the World Bank (WB) and International Monetory Fund (IMF) served as lender of last resort. However, certain conditionalities were linked to WB and IMF loans, for the most part forcing borrowers to liberalise national economies. According to Mbaya (2003:51) this led to state bankruptcy as nationalised companies were sold-off at very low prices. In addition, many jobs in the public sector were also shed.

The decline of commodity prices has severely hurt the economies of many African counties. The dependence of countries on primary goods as exports has led to terms of trade problems, as the relative purchasing power of exports to imports constantly decline. As an example the decline of copper prices has a severely adverse effect on the Zambian economy.

Unfavourable international trade conditions, notably with regards to agricultural subsidies have contributed in this regard. Mills (2002:86) notes that the 350 billion US dollars in subsidies provided by OECD countries to their agricultural sectors is higher than the collective GDP (Gross Domestic Product) of all 48 counties in sub-Saharan Africa (300 billion US dollars). Organisation for Economic Cooperation and Development (OECD) members, most notably the EU, USA and Japan, subsidise their farmers, allowing them to undersell more efficient farmers in developing countries on world markets (Macdonald, 2002:2). Thus, farmers are often denied an 
income they might have otherwise acquired, while state income potentially used to provide safety nets, is diminished.

Macro-economic instability brought on by a lack of revenue, has also led to states skimping on necessary expenses, such as investment in education and maintenance of roads. By 1993 fewer children were enrolled in schools in Zambia, Malawi and Lesotho than at independence (Kennedy, 1993:215). These factors perpetuate the low-tech nature of many of these national economies, in addition to increasing the vulnerability of individuals and households.

\subsubsection{Microlevel impacts}

On the microlevel there have been numerous factors impacting on individual and household livelihoods. The privatisation of agriculture arguably had detrimental effects, especially in the case of Malawi. The absence of marketing instruments such as grain marketing boards as a result of conditionalities accompanying Structural Adjustment Programmes (SAPs). The guaranteed market that peasant farmers had under various grain marketing boards, such as the Agricultural Marketing and Development Corporation (ADMARC) in Malawi, was eliminated with privatisation. For example, ADMARC used to travel to remote areas to buy "whatever the farmers had" (World Development Movement, 2002:30). The decline accompanying abolition of fertiliser subsidies also had severe consequences. According to Patel and Delwiche (2002) fertilisers cost two to six times more in Africa than in Europe or the USA.

Vulnerability is also increased due to environmental degradation. According to Devereux (2002:76) Malawi has experienced decreased soil fertility throughout the 1990s. Soils have been overworked, leading to a loss of nutrients. In Lesotho large-scale soil erosion has remained relatively unchecked and is still continuing today and has been exacerbated by urban encroachment (Mphale, et al., s.a:24).

Increased mechanisation and especially the closure of unproductive mines in South Africa have in the last decade especially led to a loss of employment for migrant labourers from many neighbouring countries. In Lesotho for example, this led to a significant decline in remittances from migrant workers in South Africa, which had been a key contributor to GDP and household livelihoods in that country (FAO/WFP, 2007:2). 


\subsection{Climate change}

The discussion until now has made very little reference to the specific risks pertaining to the most common livelihoods patterns in Southern Africa. It is well known that agriculture represents the main livelihood strategy for most households in Southern Africa, most of which is subsistence agriculture. Rockström et al. (2004:1111) note that rain-fed agriculture is practiced on $97 \%$ of agricultural lands in sub-Saharan Africa. In addition the consensus seems to be that erratic rainfall due to global warming and climate change is likely to increase (Mason \& Joubert, 1997; IPCC, 2007). ${ }^{3}$ Thus, for many, droughts and floods may not only impact on access to food due to higher prices, but also due to declining own production. The cumulative effects of such recurrent shocks might also be very severe. Thus, it seems that climate change is likely to bring about further livelihoods erosion for various Southern Africans in the future.

\subsection{Discussion}

From the above it seems that a linear logic would dictate that the occurrence of food security crises, to a large extent driven by HIV and AIDS, might become a distinct possibility with sustained high infection rates, while an increasing number of people become unable to cope with such an infection. This process will in part be determined by the extent to which the spread of HIV can be managed (through e.g. improved antiretroviral treatment distribution and behaviour change) as well as how processes of livelihoods degradation will pan out over time. However, HIV and AIDS prevalence are likely to impact also on the process of livelihoods degradation and vice versa, notwithstanding possible increased vulnerability due to climate change. Caution is, however, required. The risk exists of referring to underdevelopment and livelihoods erosion as an objective process. While many of the macrolevel processes such as poor terms of trade, a lack of government revenue and climate change described above might be expected to be a constant for the foreseeable future, most of the microlevel factors (e.g. job losses on South African mines) are a function of the political and economic climate in a specific geographic area at a specific point in time. In other words these factors should not

3 The IPCC (2007:8) states that agricultural production in Africa is expected to be severely compromised. According to this source rain-fed agriculture may decline by up to $50 \%$. 
necessarily manifest as a consistent regression of livelihoods, though it does seem likely.

To conclude this section, it can be stated that livelihoods and food insecurity are impacted on by numerous factors. HIV and AIDS are certainly such factors. However, this is not the driving force behind food insecurity, though it may be central to the decline of specific individuals and households. Furthermore, food insecurity is chronic in many instances, while it escalates due to (seemingly increasing) underlying vulnerabilities, coupled with severe shocks to food production. Thus, distinguishing between a state of famine and nonfamine state is not very useful. Analyses would be better served by focusing on the various forces driving vulnerability to food insecurity with an eye on disaster mitigation and sustainable food security, as opposed to merely informing the appropriation of humanitarian aid during specific crisis events, as was the case during the 2001-2003 crisis. Such analyses may, for example, include issues around livelihoods diversification, the intergenerational loss of knowledge and climate change/adaptation to climate change.

\section{Conclusion}

This article provides an overview of the NVF debate. The basic premise by De Waal as well as the most significant points of criticism it has evoked are described in order to determine the use of the NVF hypothesis as a tool for analysing Southern African food security.

Whether a famine is viewed as a process or as an event/outcome, there is an apparent impossibility of teasing out the exact extent of the impact of HIV and AIDS at the aggregate level. In addition, some of the assumptions it is grounded in have been disputed, due to insufficient evidence. In this regard, especially, the rural bias of the NVF hypothesis and the fact that food insecurity seems to be reduced to one factor is noteworthy. However, the NVF hypothesis does highlight certain important processes taking place, increasing vulnerability to food security shocks for many Southern Africans. Thus this article suggests that the role of HIV and AIDS should rather be seen as a contributing factor to a dynamic process of vulnerability or a one of many processes contributing to vulnerable outcomes to, for example, drought induced food insecurity. HIV, AIDS and food insecurity (which is a function of various factors including HIV and AIDS) can interact to the detriment of specific individuals and households at any time. In the light of this fact, 
analyses should be cognisant of the layered or overlapping nature of various factors contributing to vulnerability.

In addition, analyses should explicitly focus on the vulnerability process and not necessarily on specific incidences of "famine" or food security crisis. Suffering for many Southern Africans is chronic, while large scale shocks to food production merely exacerbate the situation by increasing its scale and severity.

HIV and AIDS, however, do imply that there are new categories of people who are potentially vulnerable in situations of food insecurity, for new reasons. These may (though not necessarily do) include prime age adults, orphans, young women, the elderly and large households.

By way of implications for humanitarian aid and/or developmental interventions, the above findings may suggest that interventions ought to be more nuanced and contextually informed. Awareness of the roles of HIV and AIDS on food security in specific households or regions ought to be carefully considered. So too should other negative processes.

\section{List of references}

BARNETT, T. \& WHITESIDE, A. 2002. Poverty and HIVIAIDS: impact, coping and mitigation strategies in Cornia, G.A. AIDS, public policy and child wellbeing. UNICEF Innocenti Research Centre. http:// www.eldis.org/go/topics/dossiers/meeting-the-health-related-needs-of-the-very-poor/povertyand-ill-health/recommended-reading\&id=19818\&type=Document Date of access: 13 Jun. 2007.

BOLTON, M. 2003. New Variant Famine or new variant nonsense? Exploring the HIV link in Zambia. http://www.foodaid.org/pdfdocs/foodforum/ C-SAFE 2004/newvariantfamine.pdf Date of access: 14 Aug. 2005.

see CONSORTIUM FOR THE SOUTHERN AFRICAN FOOD SECURITY EMERGENCY (C-SAFE)

CONSORTIUM FOR THE SOUTHERN AFRICAN FOOD SECURITY EMERGENCY (C-SAFE). 2003. Targeted food assistance in the context of HIVIAIDS. http://www.c-safe.org Date of access: 29 Jul. 2005.

DE WAAL, A. 2001. AIDS-related national crises: an agenda for governance, early-warning and development partnership. Justice Africa: AIDS and Governance Issue Paper no 1. http://www.justiceafrica.org/wp-content/ uploads Date of access: 10 Aug. 2006.

DE WAAL, A. 2003. Evidence of a New Variant Famine in Southern Africa. Justice Africa. http://www.justiceafrica.org/wp-content/uploads/2006/07/ DeWaal_NewVariantFamine.pdf Date of access: 7 Nov. 2006. 
DE WAAL, A. \& TUMUSHABE, J. 2003. HIVIAIDS and food security in Africa. A Report to the DFID. http://www.sarpn.org.za/documents/d0000235/ P227_AIDS_Food_Security.pdf Date of access: 5 Aug. 2006.

DE WAAL, A. \& WHITESIDE, A. 2003. New Variant Famine: AIDS and food crisis in Southern Africa. Lancet, 362(9391):1234-1237.

DEVEREUX, S. 2002. The Malawi famine of 2002. IDS bulletin, 33(4):70-78.

DRIMIE, S. 2005. Interview. Pretoria. 14 September.

DEVEREUX, S. 2006a. Cash transfers and social protection. Paper prepared for the regional workshop on "Cash transfer activities in Southern Africa", co-hosted by the Southern African Regional Poverty Network (SARPN), Regional Hunger and Vulnerability Programme (RHVP) and Oxfam GB 910 October 2006, Johannesburg, South Africa. http://www.ids.ac.uk/ids/ socialprotection/pdfs/Devereux\%202006\%20-\%20Cash\%20Transfers\%20 workshop\%20(Oct-06).pdf Date of access: 12 Oct. 2006.

DEVEREUX, S. 2006b. Desktop review: identification of methods and tools for emergency assessment to distinguish between chronic and transitory food insecurity and to evaluate the effects of various types and combinations of shocks on these different livelihood groups. World Food Programme, Emergency Needs Assessment Branch (ODAN). http://www.livelihoods. org/static/sdevereux_NN338.html Date of access: 12 Oct. 2007.

DRIMIE, S. \& MISSELHORN, A. 2005. Enhancing civil society participation in SADC food security processes conference report. http://www.sarpn.org. za/documents/d0001677/Conference-report_Nov2005.pdf Date of access: 2 Oct. 2007.

ELLIS, F. 2003. Human vulnerability and food insecurity: policy implications. Paper prepared for the Forum for Food Security in Southern Africa. Norwich: University of East Anglia, Overseas Development Group.

FAO/WFP

see FOOD AND AGRICULTURAL ORGANISATION/WORLD FOOD PROGRAMME

FOOD AND AGRICULTURAL ORGANISATION/WORLD FOOD PROGRAMME. 2007. Crop and Food Supply Assessment Mission to Lesotho, 2005: Special report. http://www.documents.wfp.org/stellent/groups/ public/documents/ena/wfp068082.pdf Date of access: 1 Apr. 2007.

FRANKENBERGER, T., LUTHER, K., FOX, K. \& MAZZEO, J. 2003. Livelihood erosion through time: macro and micro factors that influenced livelihood trends in Malawi over the last 30 years. Unpublished report by TANGO International.

GRIEKSPOOR, A., SPIEGEL, P., ALDIS, W. \& HARVEY, P. 2004. The health sector gap in the Southern Africa crisis in 2002/2003. Disasters, 28(4): 388-404.

HARVEY, P. 2004a. HIVIAIDS and humanitarian action: Humanitarian Policy Group, Report 16. London: Overseas Development Institute.

HARVEY, P. 2004b. HIVIAIDS, humanitarian action and the New Variant Famine: Humanitarian Policy Group debate. http://www.odi.org.uk/HPG/ papers/HIVAIDS_meeting.pdf Date of access: 28 May 2007.

HOWE, P. \& DEVEREUX, S. 2004. Famine intensity and magnitude scales: a proposal for an instrumental definition of famine. Disasters, 28(4):353-372. 
INTERNATIONAL PANEL ON CLIMATE CHANGE WORKING GROUP II. 2007. Climate change 2007: impacts, adaptation and vulnerability. Summary for policymakers. http://www.ipcc.ch Date of access: 2 Aug. 2007.

IPPC

see INTERNATIONAL PANEL ON CLIMATE CHANGE WORKING GROUP II

ITANO, N. 2003. The famine that wasn't. Christian science monitor: 9, April.

KENNEDY, P.1993. Preparing for the twenty-first century. New York: Random House.

KIRSTEN, J.F. 2001. Sustainable development in Southern Africa: obstacles and opportunities. (In Marais, H.C., Muthien, Y., Jansen van Rensburg, N.S., Maaga, M.P., De Wet, G.F. \& Coetzee, C.J., eds. Sustainable social development: critical issues. Menlo Park: Network Publishers. p. 273-284.)

LEMKE, S.L., JANSEN VAN RENSBURG, N.S., VORSTER, H.H. \& ZICHE, J. 2001. Black African households, food security and social relations in the North-West Province, South Africa: the basis of investigation for sustainable social development. (In Marais, H.C., Muthien, Y., Jansen van Rensburg, N.S., Maaga, M.P., De Wet, G.F. \& Coetzee, C.J., eds. Sustainable social development: critical issues. Menlo Park: Network Publishers. p. 185-192.)

LOEVINSOHN, M. \& GILLESPIE, S. 2003. HIVIAIDS, food security and rural livelihoods: understanding and responding. Renewal working paper no. 2.

MACDONALD, H. 2002. Farmgate: the developmental impact of agricultural subsidies. Actionaid. http://www.ukfg.org.uk/docs/AAFarmgate\%20brief ing.pdf Date of access 13 Jul. 2005.

MARSLAND, N. 2003. Vulnerability assessment in Southern Africa: concepts, findings, strengths, challenges and future developments. (In Drimie, S. \& Lafon, M., eds. Food security in Southern Africa: causes and responses from the region. Johannesburg: IFAS. p. 59.)

MASON, S.J. \& JOUBERT, A.M. 1997. Simulated changes in extreme rainfall over Southern Africa. International journal of climatology, 17:291-301.

MATHER, D., DONOVAN, C., JAYNE, T.S., WEBER, M., CHAPOTO, A., MAZHANGARA, E., BAILEY, L., YOO, K., YAMATO, T. \& MGHENYI, E. 2004. A cross-country analysis of household responses to adult mortality in rural sub-Saharan Africa: implications for HIVIAIDS mitigation and rural development policies. Department of Agricultural Economics. Michigan: Michigan State University.

MBAYA, S. 2003. Southern African food security crisis - causes and responses. (In Drimie, S. \& Lafan, M. Food security in Southern Africa: causes and responses from the region. Partial proceedings of conference coorganised by the Southern African Regional Poverty Network, CARE International and IFAS. Held at the Human Sciences Research Council in Pretoria on the 18 March. Johannesburg: IFAS. p. 35-58.)

MCEWAN, M. 2003. Changing landscapes and outliers: macro and micro factors influencing livelihood trends in Zambia over the last thirty years. CARE Southern and Western Africa Regional Management Unit (SWARMU).

MILLS, G. 2002. Poverty to prosperity globalisation, good governance and African recovery. Cape Town: Tafelberg. 
MKANDAWIRE, R. \& MATLOSA, K. 1993. Post-colonial state and food security in Southern Africa: an overview. (In Mkandawire, R. \& Matlosa, K., eds. Food policy and agriculture in Southern Africa. Harare: SAPES Books.)

MPHALE, M.M., RWAMBALI, E.G. \& SECHABA CONSULTANTS. s.a. Lesotho Food Security Issues Paper: forum for food security in Southern Africa. Paper prepared for the Forum for Food Security in Southern Africa. http://www.odi.org.uk/food-security-forum/docs/LesothoCIP.pdf Date of access: 12 Jul. 2005.

PATEL, R. \& DELWICHE, A. Profits of famine: Southern Africa's long decade of hunger. http://www.foodfirst.org/pubs/backgrdrs/2002/f02v8n4.pdf Date of access: 13 Aug. 2005.

ROCKSTRÖM, J., FOLKE, C., GORDON, L., HATIBU, N., JEWITT, G., PENNING DE VRIES, F., RWEHUBIZA, F., SALLY, H., SAVENIJE, H. \& SHULZE, R. 2004. A watershed approach to upgrade rain fed agriculture in water scarce regions through Water System Innovations: an integrated research initiative on water for food and rural livelihoods in balance with ecosystem functions. Physics and chemistry of the earth, 29(2004):11091118.

SAVE THE CHILDREN. 2004. Food security, livelihoods and HIVIAIDS: a guide to the linkages, measurement and programming implications. http:// www.sarpn.com Date of access: 15 Oct. 2005.

SPHERE PROJECT. 2004. Humanitarian charter and minimum standards in disaster response. Oxford: Oxfam.

TANGO INTERNATIONAL. 2005. CHS regional analysis: household vulnerability and the impact of food aid. Commissioned by: consortium for Southern Africa Food Security Emergency and the World Food Programme. http://www.reliefweb.int/library/documents/2005/csafe-souafr28feb.pdf Date of access: 5 Jun. 2005.

TEMBO, N. 2003. Does HIVIAIDS imply a New Variant Famine? Alex de Waal explores hypothesis with Health Task Force. http://www.uneca. org/itca/governance/Documents/Does_HIV_imply_a_new_famine.pdf Date of access: 22 Jul. 2005.

UN/ISDR. 2004. Living with risk: a global review of disaster reduction initiatives. Geneva: United Nations.

UNAIDS. 2004. Report on the global AIDS epidemic. http://www.unaids. org/en/Publications/Corrigenda/20060721-GRO.asp Date of access: 18 Jun. 2005.

UNITED NATIONS. 2003. Organising the UN response to the triple threat of food insecurity, weakened capacity for governance and AIDS, particularly in Southern and Eastern Africa. http://www.un.org Date of access: 28 Jul. 2005.

VAN LIERRE, M.J. 2002. HIVIAIDS and food security in sub-Saharan Africa presentation at 7th annual ECOWAS Nutrition Forum Banjul, the Gambia, 2-6 September 2002. http://www.sahims.net/doclibrary/Documents/ briefcases/hivaids/estherIAIDSfoodsecuritypaperECOWAS.pdf Date of access: 13 Jul. 2005.

VAN NIEKERK, D. 2006. The different faces of vulnerability: are we making any impact at all? Jàmbá: the quarterly bulletin of the African Centre for Disaster Studies, 1(1):1-5.

WHITESIDE, A. 2002. Poverty and HIVIAIDS in Africa. Third world quarterly, 23(2):313-332. 
WIGGINS, S. 2005. Southern Africa's food and humanitarian crisis of 20012004: causes and lessons. Discussion Paper, Agricultural and Economic Society Annual Conference, Nottingham 4-6 April.

WISNER, B., BLAIKIE, P., CANON, T. \& DAVIS, I. 2004. At risk: natural hazards, people's vulnerability and disasters. London: Routledge.

WORLD DEVELOPMENT MOVEMENT. 2002. Structural damage: the causes and consequences of Malawi's food crisis, October. http://www.wdm. org.uk Date of access: 18 Oct. 2005.

\section{Key concepts:}

famine

food security

HIV and AIDS

New Variant Famine

vulnerability

Kernbegrippe:

hongersnood

kwesbaarheid

MIV en VIGS

Nuwe Variant Hongersnood

voedselsekuriteit 